DOI: https://doi.org/10.47405/mjssh.v6i7.895

\begin{tabular}{|c|c|}
\hline 4.581 & Malaysian Journal of Social Sciences and Humanities (MJSSH) \\
\hline $\begin{array}{l}\text { Malaysian Journal of } \\
\text { Social cciences and }\end{array}$ & Volume 6, Issue 7, July 2021 \\
\hline (MJ-SSH) & e-ISSN : 2504-8562 \\
\hline & $\begin{array}{l}\text { Journal home page: } \\
\text { www.msocialsciences.com }\end{array}$ \\
\hline
\end{tabular}

\title{
Perubahan Sistem dan Amalan Perakaunan Sektor Awam Malaysia Sebelum Era Milenium (1957-1999): Satu Kajian Kes Jabatan Kastam Diraja Malaysia, Sabah
}

\author{
Sulaiman Tahajuddin', Ali Hasan Buglayan² \\ 1Universiti Malaysia Sabah (UMS) \\ 2Jabatan Kastam Diraja Malaysia \\ Correspondence: Sulaiman Tahajuddin (sulaiman@ums.edu.my)
}

\begin{abstract}
Abstrak
$\overline{\text { Pada pertengahan tahun 1980an para sarjana ternama dalam bidang perakaunan menyatakan bahawa }}$ masih banyak yang perlu diketahui dengan lebih dalam mengenai perubahan perakaunan pengurusan. Tidak lama selepas itu, iaitu pada awal 1990an, banyak kajian yang dilakukan menjurus kepada perubahan perakaunan pengurusan dalam perspektif pendekatan kualitatif. Walau bagaimanapun, majoriti para sarjana masih lagi berpandangan bahawa di sebalik banyaknya kajian yang telah dibuat mengenai perubahan perakaunan pengurusan, mereka tetap berpandangan bahawa masih banyak lagi yang perlu diketahui. Hampir lebih dari 30 tahun selepas para sarjana memperkatakan mengenai perkara ini, masih lebih banyak lagi mengenai perubahan perakaunan pengurusan yang perlu dikaji untuk diketahui termasuklah (1) faktor yang mendorong kepada proses perubahan, (2) proses perubahan, dan (3) kesan akhir yang terjadi hasil dari proses perubahan tersebut. Melalui perspektif dan pendekatan kualitatif, kajian ini menggunakan konsep Isomorfisme dari Teori Institutional Sosiologi Baharu (NIS) yang dibangunkan oleh Dimaggio \& Powell (1983) untuk memahami dan menerangkan kenapa dan bagaimana perubahan organisasi dan perubahan amalan perakaunan berlaku dalam Jabatan Kastam Diraja Malaysia Sabah (JKDMS) bermula era kemerdekaan sehingga ke era sebelum Milenium bermula. Dapatan kajian menunjukkan dengan jelas bahawa tekanan dalam bentuk Paksaan adalah lebih dominan berbanding tekanan dalam bentuk Normatif dan Mimetic dalam membentuk perubahan di JKDMS.
\end{abstract}

Kata Kunci: kualitatif, perubahan, perakaunan, sektor awam, Teori Isomorfisme

\section{Malaysian Public Sector Management Accounting Changes before The Millenium Age (1957-1999) : A Case Study of Royal Custom Department, Sabah}

\begin{abstract}
In mid 1980s the scholars in management accounting in particular argued that there is still much more need to be known about the management accounting change. Not so long after that, which is early $1990 \mathrm{~s}$, there were many researches had been carried out mainly to focus on the management accounting change within the perspective of qualitative approach. However, many scholars are still argue that besides the abundant research on the management accounting change, there is still a lot more yet to be known. Nearly after almost 30 years since the early scholars have said about this, it is still being argued that there are many more to be known about the management accounting change
\end{abstract}


including (1) the factors that promote the change, (2) the process of change, and (3) the ultimate consequences of the process of change. Through the qualitative perspective and approach, this research employs the Isomorphism concept under the umbrella of New Institutional Sociology theory that was developed by DiMaggio and Powell (1983) to understand and explain of why and how the organizational change, and the management accounting change system and practices take place at Jabatan Kastam Diraja Malaysia Sabah (JKDMS). The findings of this research strongly demonstrate that the Coercive pressure, as compared to the Normative and Mimetic pressures is more dominant in triggering and creating change at JKDMS.

Keywords: qualitative, changes, accounting, public sector, Isomorphosim Theory

\section{Pengenalan}

Kajian ini bertujuan untuk memahami dan seterusnya menerangkan bagaimana perubahan organisasi, perubahan perakaunan pengurusan dan perkaitan antara keduanya berlaku dalam Jabatan Kastam Diraja Malaysia Sabah (JKDMS). JKDM merupakan salah satu jabatan yang ditubuhkan oleh kerajaan Malaysia dengan fungsi utama untuk memungut cukai tidak langsung. Pemilihan JKDMS adalah atas dasar kepercayaan dan keyakinan penyelidik bahawa setiap sistem dan amalan organisasi serta perubahan yang dialaminya adalah berkait rapat dengan konteks dan persekitaran di mana ianya berada (Moilanen, 2008).

Di Malaysia, inisiatif perubahan dalam sistem pentadbiran sektor awam sebenarnya telah lama berlaku seiring dengan tahun kemerdekaan sejak 1957. Menurut Pertubuhan Bangsa-Bangsa Bersatu (PBB), inisiatif perubahan sistem dan amalan pentadbiran awam di Malaysia adalah didorong oleh keinginan negara tersebut untuk meningkatkan taraf hidup rakyatnya melalui penambahbaikan dan inisiatif pemodenan pentadbiran sektor awam yang berterusan (PBB, 1995).

Ringkasnya, terdapat banyak faktor yang telah mendorong negara, kesatuan dan juga organisasi untuk mengubah sistem dan amalan pentadbiran mereka. Walau bagaimanapun, para sarjana dan ahli industri sepakat menyatakan bahawa faktor utama yang telah mendorong perubahan ini adalah seperti NPM (New Public Management - Pengurusan Awam Baharu), globalisasi dan juga kemajuan teknologi. Satu perkara penting yang perlu diambil perhatian mengenai perubahan organisasi ini khususnya adalah mengenai apa yang telah dikatakan oleh Christiaens dan Rommel (2008) serta Hassan (2015) bahawa walaupun banyak yang telah diperkatakan mengenai perubahan dalam dekad ini tetapi kita perlulah berhati-hati kerana masih banyak yang kita perlu ketahui mengenai kesan dan arah tuju perubahan tersebut.

\section{Sorotan Literatur}

Perakaunan dapat ditakrifkan sebagai satu proses yang melibatkan tindakan mengenal pasti, mengukur, merekod, menyenaraikan, mengklasifikasikan, menganalisa urusniaga organisasi, dan seterusnya melaporkannya dalam bentuk maklumat perakaunan khususnya dalam bentuk penyata kewangan (Tahajuddin, 2013). Manakala, Perakaunan Pengurusan merupakan salah satu cabang dalam bidang perakaunan. Ianya ditakrifkan sebagai cabang perakaunan yang berfungsi untuk membekalkan maklumat-maklumat berkaitan kepada para pengurus atau pihak yang membuat keputusan untuk membolehkan mereka membuat keputusan yang tepat dan berkesan (Horngren, Sundem, Burgstahler and Scharzberg, 2014:21). Sunarni (2013) mendefinisikan perakaunan pengurusan sebagai cabang perakaunan yang orientasi penggunaan dan tujuannya ialah untuk aktiviti dan perancangan pengurusan.

Dalam perkaitannya dengan organisasi, Hongren (2014:22) berpendapat bahawa terdapat dua fungsi utama perakaunan pengurusan iaitu berfungsi untuk menyedia dan memberikan maklumat berkaitan yang digunakan terutamanya dalam proses pembuatan keputusan. Kedua, ianya juga berfungsi untuk membolehkan organisasi untuk merancang dan mengawal operasi-operasi organisasi agar ianya 
mencapai misi dan objektif organisasi. Kajian empirikal melibatkan pandangan para akauntan pengurusan oleh Yazdifar dan Tsamenyi (2005) menunjukkan beberapa dapatan penting berkaitan fungsi dan peranan perakaunan pengurusan di peringkat organisasi. Pertama, mereka mendapati bahawa pada tahun 1990an, perakaunan pengurusan dilihat lebih berfungsi sebagai alat yang digunakan untuk mengukur pencapaian dan prestasi organisasi, selain daripada digunakan untuk mengawal kos dan kewangan organisasi. Kedua, dapatan kajian mereka juga mendapati bahawa pada masa akan datang, fungsi dan peranan perakaunan pengurusan akan lebih tertumpu kepada penilaian atau ukuran prestasi atau pencapaian, kawalan kos dan kewangan, pengurusan modal kerja dan kewangan jangka pendek, penambahbaikan produktiviti, pengurusan sistem teknologi maklumat, pentafsiran dan pelaporan akaun, dan seterusnya pembuatan dan perancangan strategik.

Dari sudut alat atau teknik perakaunan pengurusan, Yazdifar dan Tsamenyi (2005) mendapati bahawa pada tahun 1990an dan juga pada masa akan datang, teknik seperti bajet, analisis varians, ramalan pusing ganti dan perakaunan pengurusan strategik adalah antara yang paling popular digunakan oleh para akauntan pengurusan dalam menjalankan fungsi mereka.

Dari segi fungsi, organisasi merupakan satu entiti sosial yang diwujudkan oleh individu atau sekumpulan individu sebagai satu platform untuk merealisasikan objektif-objektif tertentu. Secara asasnya, majoriti ahli akademik dan juga pemain industri mendefinisikan organisasi sebagai sekumpulan individu yang saling bekerjasama demi untuk mencapai sesuatu tujuan (Contoh: Anggestam, 2006; Nadler dan Tushman, 1980; Adler dan Jelinek, 1986).

\section{Definisi Perubahan dan Perubahan Organisasi}

Menurut Vasile (2014) dan juga Budai (2011), berdasarkan analisis mereka menerusi penulisan dan penyelidikan berkaitan perubahan organisasi, mereka menyatakan bahawa tidak ada satu definisi unggul yang diterima umum sebagai bersifat komprehensif mengenai perubahan organisasi kerana perubahan organisasi itu dari segi sifatnya adalah bergantung kepada proses perubahan organisasi yang bersifat unik dan bergantung kepada situasi persekitarannya yang juga unik, selain perspektif bagaimana ianya dikaji atau dilihat juga berbeza-beza. Walau bagaimanapun, Vasile (2014) merumuskan bahawa majoriti sarjana menyatakan perubahan organisasi akan melibatkan aspek seperti perubahan bentuk organisasi, perubahan detik temporal dan juga perubahan keadaan entiti organisasi tersebut. Dalam konteks organisasi sebagai elemen sosial, Dillard, Rogers dan Yuthas (2011) mendefinisikan perubahan sebagai satu fenomena terhasil daripada kombinasi antara daya atau faktor dalaman dan luaran organisasi yang bertindak ke atas organisasi, yang mana pada akhirnya akan memaksa organisasi untuk bertindak balas dan seterusnya mengubah lanskap persekitaran organisasi tersebut. Ini juga selaras dengan definisi yang diberikan oleh Lunenberg (2010) yang bermaksud bahawa perubahan organisasi ialah pergerakan atau perpindahan sesebuah organisasi dari keadaan sedia ada atau masa kini kepada keadaan masa akan datang yang diinginkan dengan tujuan untuk meningkatkan kecekapannya.

Majoriti sarjana menyatakan bahawa faktor yang mendorong kepada berlakunya perubahan organisasi dapat dibahagikan kepada dua kumpulan yang utama iaitu faktor luaran dan juga faktor dalam organisasi (Contoh: Khan dan Hashim, 2014; Lunernberg, 2010; Tahajuddin and Sulaiman, 2021; Tahajuddin, Singh and Buglayan, 2020; Tahajuddin, 2020; Tahajuddin, 2013. Faktor luaran merujuk kepada persekitaran luar organisasi di mana ianya beroperasi seperti sistem politik dan dasar-dasar negara atau kerajaan tempatan, kemajuan teknologi, globalisasi, kegawatan ekonomi global dan juga nasional, dan peranan institusi persekitaran. Manakala faktor dalaman organisasi merujuk kepada faktor dalam organisasi seperti budaya organisasi, peranan pihak pengurusan organisasi, peranan pemimpin atau kepimpinan organisasi dan juga peranan kesatuan sekerja peringkat organisasi.

\section{Peranan Budaya Organisasi}

Dari perspektif budaya, Zia-ul-Haq dan Kamran (2015) menyatakan bahawa salah satu faktor penentu yang menyebabkan sesebuah organisasi berubah adalah faktor budaya organisasi tersebut dan juga budaya lain-lain organisasi yang berada dalam persekitarannya. Janićijević (2012) mendefinisikan 
budaya sebagai satu sistem tanggapan, pandangan, nilai-nilai, norma dan tingkah laku yang dimanifestasikan dalam bentuk simbol yang mana ianya terbentuk dan diwujudkan oleh ahli organisasi melalui pengalaman bersama. Janićijević (2012) seterusnya menyatakan bahawa budaya ini akan menentukan cara mana ahli organisasi mentafsir dan menilai apa yang berlaku dan perlu dilakukan dalam persekitaran mereka.

\section{Pemimpin}

Pundziene dan Duobiene (2006) melalui analisis mereka mengenai literatur berkaitan perubahan organisasi (contoh: Van de Ven and Poole, 1995; Schalk dll, 1998) merumuskan bahawa perubahan organisasi tidak akan berlaku tanpa adanya tindakan dari 'manusia' yang menjadi sebahagian dari elemen yang terdapat dalam organisasi. Menurut Nieves dan Siegarra-Ciprés (2015), pemimpin yang berinovasi akan membawa perubahan kepada organisasi. Mereka juga berpendapat bahawa inovasi yang datang dari buah fikiran pemimpin biasanya diperolehi dari pergaulan pemimpin dengan pihak luar dan dalam organisasi itu. Dalam erti kata lain, pergaulan atau hubungan sosial yang berkualiti antara pemimpin organisasi dengan pihak luar dan orang bawahannya akan mempengaruhi proses perubahan organisasi.

\section{Peranan Kesatuan Sekerja}

Kesatuan sekerja merupakan organisasi kecil dalam sesebuah organisasi yang tujuan utamanya adalah bersuara bagi pihak para pekerja organisasi secara keseluruhan yang selalunya melibatkan kebajikan para pekerja termasuklah hal-hal yang berkaitan dengan gaji, keselesaan tempat bekerja, kemudahan pekerjaan dan kesihatan, keselamatan, pencen dan persaraan serta lain-lain lagi. Kajian daripada Khan dan Hashim (2014) mengenai General Motors di Amerika Syarikat mendapati pertembungan dan ketegangan yang wujud di antara pihak pengurusan General Motors dan kesatuan sekerja mereka adalah berpunca dari perbezaan pendapat mengenai gaji dan imbuhan yang patut dibayar kepada para pekerja sokongan General Motors. Demi mengelakkan masalah yang lebih besar dan meredakan ketegangan antara organisasi dan kesatuan sekerja, pihak pengurusan General Motors akhirnya terpaksa mengubah beberapa struktur sedia ada khususnya yang berkaitan dengan sistem pengurusan modal manusianya termasuklah memberhentikan sebahagian pekerja dan juga mengurangkan kadar gaji kepada yang lebih rendah.

\section{Peranan Institusi}

Menurut Wezel dan Saka-Helmhout (2005), para sarjana dan penyelidik dalam bidang perubahan organisasi sependapat bahawa persekitaran organisasi di mana organisasi berada adalah salah satu faktor yang sangat signifikan dalam mendorong organisasi untuk berubah. Sementara itu Rababa'h (2014) melihat peranan institusi dari sudut sumber rujukan kepada norma-norma semasa amalan organisasi dalam insitusi tersebut. Rababa'h mendapati pada era globalisasi kebanyakan organisasi akan mengamalkan norma-norma terkini yang mungkin datangnya dari negara-negara lain. Dalam kes ini Rababa'h mendapati bahawa organisasi akan mengamalkan satu-satu amalan (amalan perakaunan pengurusan) hanya kerana semua organisasi dalam institusi tersebut juga mengamalkannya. Dalam erti kata lain, organisasi harus berubah agar kelihatan sama seperti organisasi lain yang berada dalam persekitarannya.

\section{Peranan Teknologi}

Peranan kemajuan teknologi dalam membawa perubahan ke atas organisasi adalah antara yang mendapat perhatian di kalangan para sarjana, pemain industri dan para penyelidik khususnya dalam aspek perubahan organisasi (Markus dan Robey, 1988). Antara kajian awal berkenaan kesan perubahan teknologi ke atas perubahan organisasi adalah Tyre dan Hauptman (1992). Dalam kajian beliau, Tyre dan Hauptman mendapati bahawa sekiranya organisasi (khususnya organisasi perkilangan) memperkenalkan satu teknologi baharu dalam operasi mereka maka organisasi tersebut akan berusaha untuk mengadaptasi sebarang ketidakpastian yang mungkin ditimbulkan oleh teknologi baharu yang 
diperkenalkan. Tyre dan Hauptman (1992) berpendapat bahawa pada akhirnya, proses mengadaptasi ketidakpastian ini akan membuat organisasi tersebut mengalami perubahan.

Kajian dari Budai (2011) pula menunjukkan bahawa kesan teknologi adalah seiring dengan kesan persaingan yang sengit antara sesama organisasi persekitaran. Menurut Budai (2011) bila persaingan semakin kuat maka kecenderungan organisasi untuk mengadaptasi teknologi baru akan menjadi semakin tinggi yang akhirnya akan mengubah budaya kerja, sistem dan juga struktur organisasi tersebut. Pandangan Budai (2011) disokong oleh kajian konsep oleh Cha dan Cha (2014) Innes dan Mitchell (1990) yang menyatakan bahawa organisasi akan sering mengadaptasi perubahan teknologi melalui penggunaan teknologi terkini dan relevan dalam operasi mereka agar dapat mengekalkan dan memperbaiki kelebihan kompetitif mereka. Seterusnya, Lim dan Yazdanifard (2014) juga menyatakan bahawa melalui perubahan teknologi yang diadaptasi oleh organisasi akan menjadikan produktiviti, kecekapan dan keberkesanan para pekerja akan meningkat, yang mana ianya merupakan elemen penting dalam persaingan yang kompetitif.

\section{Peranan Tekanan Pihak Atasan}

Pihak atasan boleh dilihat sebagai individu, jabatan atau organisasi yang berada pada hierarki lebih tinggi dari organisasi melalui pertalian seperti pemilikan, bidang kuasa, bantuan kewangan dan sebagainya. Dalam kes ini, Lunenberg (2010) yang mengkaji perubahan organisasi sekolah kerajaan menyatakan bahawa tekanan dari pihak atasan sekolah seperti jabatan pendidikan, kementerian pendidikan dan unit-unit lain yang memantau sekolah tersebut telah memaksa mereka untuk mengubah suai dasar dan polisi yang berkaitan dengan sistem pembayaran gaji, kadar bayaran dan polisi layanan ke atas pekerja-pekerja wanita di sekolah tersebut.

\section{Kegawatan Ekonomi dan Kewangan}

Menurut Lunenberg (2010) berdasarkan sorotan literatur menunjukkan bahawa kegawatan ekonomi dan masalah kewangan yang melanda persekitaran organisai atau yang sedang dihadapi oleh organisasi akan menyebabkan moral ahli organisasi menjadi lemah, dan akhirnya akan menyebabkan pencapaian organisasi secara keseluruhan menjadi tidak baik. Ini akan memaksa organisasi untuk melakukan perubahan tertentu untuk meningkatkan moral dan pencapaian organisasi secara keseluruhan. Dapatan Khan dan Hashim (2014) membuktikan bahawa apabila ekonomi global menurun dan berada dalam keadaan kegawatan, organisasi besar seperti General Motors telah membuat perubahan drastik dalam sistem pengurusan sumber manusianya dengan tujuan untuk memastikan organisasi tersebut sentiasa berdaya saing dan dapat meneruskan operasinya seperti biasa.

\section{Metod Kajian}

Kajian ini bertujuan untuk memahami proses perubahan dalam sistem dan amalan perakaunan pengurusan di dalam organisasi JKDMS. Tahajuddin (2013) menyatakan bahawa dalam melakukan kajian mengenai perakaunan pengurusan dalam konteks organisasi seorang penyelidik haruslah memahami konsep dan definisi perakaunan pengurusan tersebut. Beliau menyatakan bahawa sekiranya perakaunan pengurusan dilihat sebagai elemen teknikal, maka kajian berteraskan kaedah kuantitatif ialah bersesuaian digunakan sebagai kaedah kajian. Sebaliknya menurut beliau lagi, sekiranya perakaunan pengurusan dilihat sebagai elemen yang terdiri daripada proses dan melibatkan unsur-unsur tingkah laku manusia, maka kaedah kualitatif ialah kaedah yang paling sesuai untuk digunakan.

\section{Kerangka Teori Kajian}

Laughlin (1991) dan Broadbent dan Laughlin (2005) menegaskan bahawa dalam membuat penyelidikan berkaitan perakaunan dalam organisasi khususnya berkaitan dengan proses perubahan perakaunan, maka seseorang penyelidik itu memerlukan satu kerangka teori yang bersesuaian. Beliau menyatakan bahawa kerangka teori yang digunakan bukanlah untuk menguji ketepatan teori tersebut tetapi sebaliknya sebagai panduan kepada penyelidik dalam proses melakukan penyelidikan tersebut. 
Dalam kajian ini, penyelidik berpandangan bahawa teori atau konsep Isomorfisme yang dibangunkan oleh DiMaggio dan Powell (1983) bersesuaian digunakan untuk memahami dan menerangkan mengenai bagaimana proses perubahan sistem dan amalan perakaunan pengurusan di JKDMS berlaku untuk tempoh dari tahun 1963 hingga 2015. Tempoh ini dipilih selaras dengan cadangan dan pandangan yang dinyatakan oleh ahli-ahli akademik seperti Lind, (2001); Bouma dan Atkinson (1995:114); Bailey, (1994:36); Otley, (1990) yang mengatakan bahawa kajian yang mengambil kira faktor tempoh masa akan menjadikan dapatan kajian tersebut lebih berkualiti kerana hanya melalui analisis fenomena dan aktiviti yang telah berlaku dalam konteks tempoh masa akan memberikan gambaran yang lebih komprehensif dan terperinci mengenai perubahan yang telah berlaku. Tempoh tersebut juga dipilih berdasarkan keyakinan dan pandangan penyelidik bahawa terdapat beberapa kriteria unik yang berlaku atau dimiliki oleh JKDMS untuk menjadikannya sesuai dipilih sebagai kajian kes dan juga penentuan tempoh masa yang dinyatakan di atas. Ini termasuklah bahawa Sabah memiliki ordinan-ordinan berkaitan perkastaman dan percukaian sendiri sebelum tahun 1963; Sabah mempunyai kuasa-kuasa autonomi yang diperakukan oleh Persekutuan Malaysia ketika pembentukan Malaysia; perubahan dasar dan undang-undang berkaitan cukai dan perkastaman sepanjang tempoh tersebut contohnya pengenalan GST pada April 2015. Kriteria keunikan tersebut (Seawright and Gerring, 2008) menjadikan JKDMS sesuai untuk dijadikan kajian kes dalam konteks penyelidikan ini.

Berkenaan dengan Isomorfisme yang dibangunkan oleh DiMaggio dan Powell (1983), proses perubahan yang berlaku boleh diterangkan atau difahami melalui tiga peringkat. Pertama, perubahan berlaku disebabkan oleh proses Mimetic iaitu organisasi berubah kerana cuba untuk meniru atau kelihatan bertindak sama seperti organisasi lain yang lebih berjaya. Kedua, perubahan berlaku disebabkan oleh proses Paksaan iaitu sesebuah organisasi itu mengalami perubahan kerana dipaksa berubah, khususnya organisasi yang berada dalam kawalan pihak atau organisasi lain. Ketiga, perubahan berlaku kerana organisasi merasakan mereka perlu dilihat sebagai organisasi yang bertindak dan mengamalkan sistem dan amalan yang sama seperti organisasi lain yang berada dalam persekitaran mereka, yang dikenali sebagai Isomorfisme Normatif.

Penyelidik percaya bahawa JKDMS sebagai sebuah organisasi sektor awam yang telah dan sedang mengalami proses perubahan yang dapat diterangkan dan difahami melalui tiga proses seperti yang dinyatakan oleh DiMaggio dan Powell (1983). Pada masa yang sama, penyelidik juga tidak menolak kemungkin bahawa terdapat teori lain seperti teori Perubahan Organisasi (Laughlin, 1991) dan Political Economy Theory (Karl Marx) yang boleh diguna pakai dalam kajian ini.

\section{Kaedah Kajian}

Kajian ini telah dilakukan menggunakan pendekatan kajian kes. Penyelidik telah mengenal pasti Jabatan Kastam Diraja Malaysia Sabah sebagai kes kajian. Kajian kes dipilih berdasarkan pandangan bahawa hanya melalui kajian kes sahaja pemahaman dan penerangan mengenai proses perubahan sistem dan amalan perakaunan pengurusan dapat dilakukan dengan terperinci dan menyeluruh (Caccia and Steccoloni, 2006; Gurd, 2008; Namazi, 2013; Ryan dll., 2002; Tessier dan Otley, 2012). Sebagai contoh, kajian yang dilakukan oleh Eriksson, Holden, Williams dan Delive (2016) mengenai persoalan kenapa dan bagaimana beberapa hospital menggunakan pendekatan tertentu dalam melaksanakan fungsi utama mereka menunjukkan bahawa hanya dengan mengkaji organisasi tersebut secara mendalam dan juga bersama dengan persekitaran atau konteksnya maka persoalan kajian tersebut dapat dijawab dengan jayanya. Dapatan Eriksson dll. (2016) menunjukkan bahawa amalan organisasi setiap kes yang dikaji terbentuk dari interaksi pelbagai faktor persekitaran yang bersifat unik antara satu sama lain. Menurut Cosimato, Torre, dan Troisi (2015), dengan kajian kes interaksi pelbagai faktor luaran dan dalaman organisasi yang terlibat dalam proses perubahan organisasi telah dapat diterangkan dengan lebih terperinci.

Selain itu, penyelidik juga memilih JKDMS atas dasar penyelidik ialah pada masa yang sama bekerja di JKDMS oleh itu mempunyai kelebihan untuk lebih memahami situasi perubahan yang bakal dikaji. Ini selaras dengan pandangan Tessier dan Otley (2012) yang menyatakan bahawa sekiranya penyelidik atau salah seorang penyelidik pernah atau sedang bekerja dengan organisasi yang sedang dikaji maka ianya boleh memberi kelebihan dari segi dapatan dan kualiti data yang diperolehi kerana proses 
perubahan organisasi telah disaksikan dan dialami oleh penyelidik tersebut, dan ianya sangat berguna dalam proses kajian tersebut. Pandangan Tessier dan Otley (2012) adalah selaras dengan kenyataan Malhotra dan Hinings (2015) yang membuktikan bahawa sekiranya para penyelidik mempunyai pengetahuan asas atau sejarah mengenai kes atau organisasi yang telah dikaji maka adalah mudah untuk para penyelidik untuk mendapatkan lebih banyak data yang padat dan berkualiti.

\section{Kutipan dan Analisis Data}

Bryant (2006) dan Bruce (2007) menegaskan bahawa dalam penyelidikan yang melibatkan pemahaman mengenai sesuatu proses perubahan dalam sesebuah organisasi maka penting bagi seorang penyelidik untuk mendapatkan data dari pelbagai sudut khususnya melalui pengalaman dan ingatan individu yang berada dalam organisasi tersebut. Para penyelidik yang menggunakan pendekatan kualitatif, mereka seharusnya menggunakan kaedah yang membolehkan penyelidik mendapatkan data yang 'dalam' dan menyeluruh (Bruce, 2007). Kutipan data atau maklumat dari pelbagai kaedah lain juga adalah sangat penting untuk memastikan dapatan yang diperolehi adalah berkualiti tinggi (Andon dll., 2007 dan Ryan, Scapens dan Theobald, 2002; Turner, 2010). Ini adalah selaras dengan pendapat Bruce (2007) yang menjelaskan bahawa terdapat desakan agar para penyelidik khususnya penyelidikan kualitatif untuk memastikan data yang dikutip bersifat telus dan jelas. Pada masa yang sama, Onwuegbuzie, Leech dan Collins (2010) juga menyatakan bahawa pada era abad ke 21 ini, penyelidikan bersifat kualitatif seharusnya menggunakan kemajuan teknologi terkini dan kaedah-kaedah kutipan data yang lebih inovatif untuk memastikan data yang diperolehi bersifat komprehensif. Sebagai contoh, Onwuegbuzie dll. (2010) mencadangkan agar penyelidik menggunakan teknologi komputer dan rakaman video dalam kaedah pemerhatian dan penglibatan mereka dalam organisasi yang dikaji.

Oleh itu, dalam kajian ini penyelidik telah mendapatkan data dan maklumat yang berkaitan melalui pelbagai kaedah termasuk melalui temubual, kajian dan penelitian dokumen arkib, pemerhatian di lokasi, pembabitan dalam mesyuarat yang berkaitan. Yeasmin dan Rahman (2012) menggalakkan pendekatan kutipan data yang menggabungkan beberapa kaedah seperti ini dipanggil kaedah 'triangulasi'. Yeasmin dan Rahman (2012) mendefinisikan triangulasi sebagai satu kombinasi dua atau lebih teori, sumber-sumber data, kaedah atau penyelidik dalam satu kajian fenomena untuk mendapatkan kesahihan sesuatu dapatan yang mana ianya boleh digunapakai dalam kaedah kajian kuantitatif dan juga kualitatif.

Menurut Meijer, Verloop dan Beijeard (2002), Stefura (2014) dan Rabionet (2011), dalam kajian bersifat kualitatif, perkara paling penting yang perlu diambil kira oleh seseorang penyelidik untuk memastikan gambaran sebenar fenomena sosial yang sedang dikaji adalah bersifat sebenar ialah 'kesahihan dalaman' yang juga berkait rapat dengan kredibiliti data dan analisis data (Patton, 1999). Ini termasuklah sebagai contoh telah menggunakan dua atau lebih kaedah kutipan dan analisis data, menggunakan lebih dari seorang penemubual, dan juga menemubual lebih dari seorang pegawai (Stefura, 2014). Kesahihan dalaman hanya akan diperolehi sekiranya data yang dikutip adalah bersifat komprehensif atau menyeluruh (Mathison, 1988; Meijer dll., 2012; Patton, 1999; Stefura, 2014), dan ianya boleh dicapai melalui kutipan data dari pelbagai sudut atau kaedah, atau apa yang dipanggil sebagai triangulasi.

\section{Hasil Kajian}

\section{Konteks Sejarah, Ekonomi dan Sosial JKDMS}

Menurut Siddique (2008), dalam proses menghadapi persekitaran yang penuh dengan cabaran dan perubahan, Malaysia telah mengalamai beberapa perubahan dalam pelbagai bentuk dan peringkat agar sentiasa dapat berdaya tahan khususnya dalam bidang ekonomi, pentadbiran, politik dan budaya. Sebelum mendapat kemerdekaan, Malaysia sebagai sebuah negara yang terdiri daripada beberapa buah kerajaan bersultan telah mengalami pelbagai proses pentadbiran termasuklah penjajahan oleh kuasakuasa asing seperti Portugis, Belanda, Jepun dan Inggeris. Malaysia sebagai sebuah negara merdeka bermula dengan Tanah Melayu pada 1957 dan kemudiannya kemasukan Sabah dan Sarawak pada 1963 
mengamalkan sistem pemerintahan Raja Berpelembagaan dan Demokrasi Berparlimen yang terdiri dari tiga peringkat kerajaan yang saling berkait iaitu Kerajaan Pusat, Kerajaan Negeri dan juga Kerajaan Tempatan. Menurut Aziz (2017) Raja Berperlembagaan adalah sebagai sebahagian sistem pentadbiran apabila Perlembagaan Persekutuan mengiktiraf kedudukan dan peranan institusi Raja atau Monarki dalam Perlembagaan (Perkara 181 Perlembagaan Persekutuan) serta diberi kuasa tertentu oleh Perlembagaan.

Dari sudut ekonomi, pembangunan Malaysia khususnya adalah bertunjangkan Rancangan Malaysia pada skala 5 tahun dan juga DEB pada skala 20 tahun. Dua objektif utama yang ingin dicapai melalui DEB adalah pembasmian kemiskinan khususnya di kalangan etnik Melayu dan Bumiputera (mengambil kira etnik dari Sabah dan Sarawak), dan juga mengurangkan jurang agihan ekonomi antara kaum di Malaysia. Menurut Iqbal, Hussin dan Seman (2014), penghujung tahun 1960an atau awal tahun 1970an menunjukkan bahawa usaha-usaha kerajaan menunjukkan pencapaian yang positif dengan kemasukan pelabur-pelabur luar di Malaysia khususnya firma-firma Jepun yang melabur dalam sektor pembuatan. Tahun 1990an hingga awal tahun 2000 merupakan tempoh masa yang dianggap sebagai tahun kemakmuran dan juga tahun kesukaran bagi Malaysia. Ini berdasarkan fakta yang menunjukkan bahawa Malaysia mengalami pertumbuhan ekonomi yang sangat pesat dengan perkembangan purata tahunan sebanyak $8.1 \%$ (UPEN). Tahun 1990an juga merupakan tahun kesukaran kepada Malaysia apabila berlaku krisis ekonomi global yang menyebabkan berlakunya kegawatan ekonomi teruk yang melibatkan negara-negara di Asia termasuklah Malaysia. Situasi ini akhirnya Malaysia terpaksa mengambil langkah-langkah drastik untuk menangani kegawatan tersebut termasuklah inisiatif penubuhan Majlis Tindakan Ekonomi Negara (MTEN) yang bertindak sebagai agensi penasihat kepada kerajaan dalam aspek pentadbiran ekonomi Negara.

Perubahan landskap politik dan ekonomi budaya selaras dengan perubahan masa juga telah memberi kesan ke atas sistem pentadbiran sektor awam Malaysia. Sebelum tahun 1990, antara inisiatif awal kerajaan Malaysia di peringkat nasional untuk memastikan sektor awam sentiasa berdaya saing adalah dengan menubuhkan satu unit yang dikenali sebagai Unit Pemodenan Tadbiran dan Perancangan Pengurusan Malaysia yang lebih dikenali sebagai MAMPU. Menjelang tahun 1990 hingga awal tahun 2000, di bawah kepimpinan Perdana Menteri pada ketika itu iaitu YAB Tun Mahathir, kerajaan telah menggubal satu visi yang lebih jelas yang dinamakan sebagai Wawasan 2020 yang antara lainnya bertujuan untuk menggariskan inisiatif dan cabaran-cabaran yang perlu dilalui oleh Malaysia untuk menjadi sebuah negara maju dan berdaya saing menjelang tahun 2020. Selaras dengan gelombang NPM di peringkat global dan juga kewujudan Dasar Pembangunan Nasional (DPN) untuk tempoh sepuluh tahun sehingga tahun 2000, Siddique (2008) menyatakan bahawa keadaan ini telah memaksa sistem pentadbiran awam di Malaysia perlu ditransfomasikan agar Wawasan 2020 dapat dicapai dengan jayanya. Banyak inisiatif yang telah dilakukan oleh kerajaan bagi mendokong Wawasan 2020 termasuklah melahirkan kakitangan sektor awam yang berpengetahuan dan berwawasan dan dilengkapi dengan kemahiran dalam bidang teknologi maklumat dan komunikasi. Untuk ini, kerajaan telah membina Koridor Raya Multimedia (MSC) pada tahun 1996 untuk mendokong inisiatif tersebut.

Pada awal tahun 2010, Perdana Menteri Malaysia YAB Dato' Seri Najib Tun Razak telah mengumumkan untuk melaksanakan satu dasar jangka panjang yang beliau namakan sebagai Program Transformasi Negara (National Transformation Programme - NTP) yang merangkumi dua komponen utama iaitu Program Transformasi Kerajaan (Government Transformation Programme - GTP) dan juga Program Transformasi Ekonomi (Economic Transformation Programme - ETP). Kedua-dua program GTP dan ETP adalah saling berkait rapat dalam konteks memacu negara ke arah kejayaan Wawasan 2020 tetapi GTP adalah program khusus yang dirangka dan dilaksana dengan melibatkan sektor awam sebagai penggerak utama dalam proses tersebut. JKDM secara amnya dan juga JKDMS secara khususnya yang merupakan salah satu jabatan kerajaan penting khususnya sebagai entiti pemungut hasil kerajaan juga tidak terlepas dari terlibat sama ada secara langsung atau sebaliknya dalam proses transformasi sektor awam Negara. 


\section{Profail JKDMS}

Sejarah JKDMS boleh dijejaki sehingga ke zaman pemerintahan kesultanan Brunei pada kurun ke 16, iaitu pada ketika Sabah atau lebih dikenali sebagai Borneo Utara masih di bawah jajahan kesultaran Brunei. Walau bagaimanapun, seperti yang diterangkan dalam Bab 4 sebelum ini, selepas kemerdekaan bersama Persekutuan Malaysia, JKDMS berada di bawah pengawasan Kementerian Kewangan melalui JKDM Malaysia atau JKDM pusat.

Gambarajah 1: Carta Organisasi JKDMS

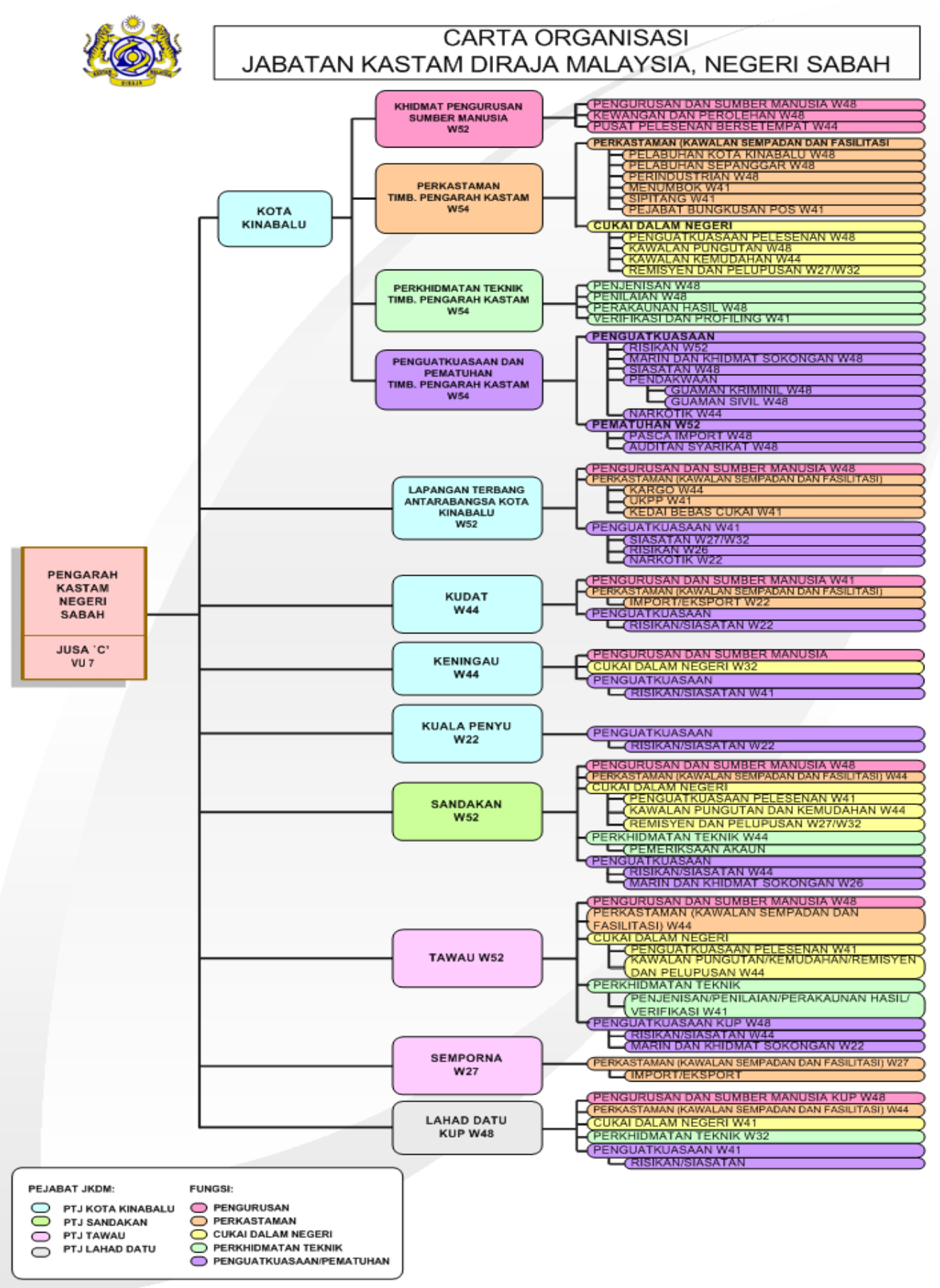


Pada ketika ini, JKDMS memiliki lebih kurang 900 orang pegawai dari pelbagai peringkat yang diketuai oleh Pengarah Kastam Negeri. Jumlah anggota ini dijangka akan meningkat lagi pada masa akan datang untuk memenuhi keperluan operasi JKDMS. JKDMS terdiri beberapa Stesen iaitu empat Stesen Besar termasuklah Kota Kinabalu, Tawau, Sandakan dan Lahad Datu. Ianya juga terdiri dari lima Stesen Daerah termasuklah Keningau, Mempakul, Menumbok, Kudat, Sipitang dan Semporna. Gambarajah 1 diatas menunjukkan carta organisasi JKDMS setakat tahun 2016.

Dari fungsi, JKDMS berfungsi sama seperti JKDM Malaysia iaitu dengan aktiviti utama terdiri daripada perkastaman, pungutan cukai dalam negeri, penguatkuasaan, pematuhan dan perkhidmatan teknik. Untuk menjalankan fungsi-fungsi asasnya, JKDMS tertakluk kepada Akta Kastam 1967 dan lain-lain akta yang berkaitan.

\section{Pola Perubahan JKDMS}

Berdasarkan dapatan kajian penyelidikan ini, penyelidik mendapati bahawa pola perubahan yang berlaku di dalam JKDMS dapat dibahagikan kepada dua agihan tempoh masa yang berbeza. Agihan tempoh masa yang pertama ialah perubahan yang berlaku sebelum akhir tahun 1990an atau lebih tepatnya tempoh masa sehingga awal tahun 2000. Manakala, untuk agihan tempoh masa yang kedua adalah melibatkan perubahan yang berlaku bermula dan selepas tahun 2000. Agihan tempoh masa atau pola perubahan ini yang berasaskan akhir tahun 1990an atau secara tepatnya pada tahun 2000 disokong oleh dapatan kajian khususnya melalui sesi temubual dan juga sokongan dokumen-dokumen sahih yang berkaitan. Majoriti pihak yang ditemubual membuat perbandingan perubahan sama ada secara khusus mengenai sistem dan amalan perakaunan pengurusan, atau perubahan umum mengenai JKDM membuat perbandingan asas kepada tempoh masa tersebut. Sebagai contoh, salah seorang yang ditemubual menyatakan:
“ Pada pandangan saya secara kasar, bercakap mengenai perubahan yang berlaku dalam Kastam Sabah, saya boleh bandingkan perkara-perkara yang berlaku sebelum tahun 2000, dan juga yang berlaku selepas tahun 2000 hingga sekarang”

Seterusnya bila disoal mengenai kenapa beliau membuat perbandingan berdasarkan tahun yang disebutkan di atas, beliau mengatakan:
“Saya adalah antara orang yang paling lama masih bertugas di Kastam Sabah, dan sudah bertugas dalam Kastam (Sabah) di banyak bahagian. Berdasarkan pengalaman saya, saya boleh nampak dengan jelas memang terdapat perbezaan yang jelas apa yang berlaku dalam Kastam sebelum dan selepas tahun 2000"

Pandangan tersebut juga disokong secara tidak langsung oleh salah seorang individu lain yang menyatakan:
“ bercakap mengenai perubahan Kastam Sabah, saya boleh katakan banyak perubahan ketara berlaku setelah berlaku perubahan kepimpinan di peringkat atasan iaitu bila Tan Sri Halil dilantik menjadi Ketua Pengarah Kastam Malaysia"

Pandangan tersebut adalah selari dengan pandangan sebelumnya mengenai tempoh asas penghujung tahun 1990an atau tahun 2000 sebagai titik asas perbandingan kerana berdasarkan rekod yang didapati dalam dokumen-dokumen berkaitan yang dirujuk oleh penyelidik menunjukkan bahawa Tan Sri Abdul Halil bin Mutalib telah dilantik menjadi Ketua Pengarah JKDM pada tarikh 1 Ogos 2000.

Walau bagaimanapun, secara kasarnya, penyelidik mendapati analisis dapatan ini menunjukkan terdapat beberapa petunjuk yang signifikan menjadikan tren atau pola agihan masa ini agak nyata. Pada dasarnya dalam konteks perubahan organisasi dan juga perubahan sistem dan amalan pengurusan 
JKDMS, penyelidik boleh membuat kesimpulan awal bahawa sebelum tahun 2000, tidak banyak perubahan signifikan yang berlaku berbanding tahun-tahun selepas tahun 2000. Sub topik seterusnya, membincangkan analisis perubahan yang berlaku secara terperinci.

\section{Perubahan Sebelum Era Milenium}

Dalam subtopik ini, perubahan yang berlaku dalam JKDMS akan dibincangkan seawal era kemerdekaan negeri Sabah pada tahun 1963, iaitu era selepas era Kolonial British bermula 1881 hingga 1963 tanpa mengambil kira era penjajahan Jepun di Malaysia. Selain itu, perbincangan akan diteruskan dengan mengambil kira perubahan yang berlaku selepas era kemerdekaan sehingga akhir tahun 1990an. Perubahan yang dimaksudkan ialah sebarang jenis perubahan yang bersifat abstrak, proses dan sistem, serta perubahan fizikal dengan mengambil kira konsep perubahan yang diterangkan oleh Laughlin (1991). Seterusnya perubahan ini pula akan dikaitkan mengenai implikasinya kepada perubahan dalam sistem dan amalan perakaunan pengurusan JKDMS.

\section{Era Kemerdekaan Sabah 1963}

Seperti yang telah dinyatakan sebelum ini, Sabah mendapat kemerdekaan dari kerajaan British pada 31 ogos 1963 yang kemudiannya menganggotai Persekutuan Malaysia pada 16 September tahun yang sama. Kedua-dua tarikh ini memberikan kesan perubahan yang paling signifikan pada JKDMS secara umumnya.

Antara implikasi ketara ke atas perubahan JKDMS adalah dari segi pentadbiran JKDMS itu sendiri. Selepas mendapat kemerdekaan, dari segi politiknya JKDMS secara automatik adalah di bawah pentadbiran kerajaan Sabah. Walaupun setelah pembentukan Malaysia pada 16 September 1963 telah berlaku dan pada masa yang sama sistem dan amalan perkastaman Tanah Melayu telah terbentuk melalui Jabatan Kastam dan Eksais Persekutuan Tanah Melayu sejak tahun 1948 lagi tetapi negeri Sabah mentadbir sistem dan amalan perkastaman secara terasing dengan beberapa Ordinan berkaitan sebagai rujukan.

\section{Era Kemerdekaan Sabah 1963: Implikasi}

Dari segi implikasinya ke atas sistem dan amalan perakaunan pengurusan JKDMS selepas diberikan kemerdekaan, semua aktiviti-aktiviti yang berkaitan dengan pungutan dan kenaan cukai khususnya dalam aktiviti perdagangan antarabangsa melalui perkapalan atau laut adalah di bawah tadbiran Jabatan Kastam dan Eksais negeri Sabah. Pada ketika ini, sistem dan amalan yang digunakan dalam aktiviti perkastaman khususnya yang melibatkan aktiviti percukaian dagangan antarabangsa adalah ditadbir secara langsung oleh kerajaan negeri Sabah tanpa perlu merujuk kepada Jabatan Kastam dan Eksais Persekutuan Tanah Melayu. Walau bagaimanapun, secara umumnya sistem dan amalan ini adalah bersamaan dengan sistem dan amalan yang ditinggalkan oleh pihak kolonial British sebelum ini.

\section{Era Selepas Pembentukan Persekutuan Malaysia 1963}

Selepas Sabah mendapat kemerdekaan dari pihak British pada 31 Ogos 1963, Sabah kemudiannya telah bersama-sama Sarawak, Persekutuan Tanah Melayu dan Singapura membentuk persekutuan yang dikenali sebagai Persekutuan Malaysia, atau lebih dikenali sebagai Malaysia sahaja pada ketika ini. Pembentukan Persekutuan Malaysia merupakan titik tolak yang telah membawa perubahan yang signifikan bukan hanya kepada Sabah sebagai sebuah kerajaan tetapi juga sistem pentadbiran jabatanjabatan yang berada di dalamnya termasuklah organisasi Kastam negeri Sabah.

Dengan terbentuknya Malaysia, pentadbiran kastam negeri adalah antara yang terlibat secara langsung untuk terikat kepada Perlembagaan Malaysia 1963, yang secara automatiknya pentadbiran kastam negeri terikat di bawah sistem pentadbiran kastam pusat yang berlokaliti di Semenanjung Malaysia. Walau bagaimanapun, Jabatan Kastam dan Eksais Malaysia Sabah masih mempunyai autonomi dari segi perlaksanaan aktiviti-aktiviti perkastaman termasuklah yang berkaitan dengan sistem 
perakaunannya yang juga melibatkan aktiviti percukaian yang merupakan komponen utama sistem perakaunan JKDMS pada ketika itu. Ini sejajar dengan autonomi dari segi penggunaan ordinanordinan negeri berkaitan sistem dan pentadbiran aktiviti kastam oleh JKDMS pada ketika itu. Pada tahun 1967, Akta Kastam 1964 telah dipinda untuk menyeragamkan aktiviti perkastaman di semua negeri yang terlibat khususnya antara Tanah Melayu, Sarawak dan Sabah. Sejak dari situ, secara umumnya prosidur operasi standad (SOP) aktiviti perkastaman di seluruh negara adalah seragam.

\section{Era Selepas Pembentukan Persekutuan Malaysia 1963: Implikasi}

Tahun 1963 juga melakar sejarah bagi JKDMS kerana keanggotaan Sabah dalam Persekutuan Malaysia menjadikan JKDMS terikat dengan Organisasi Kastam Sedunia atau lebih dikenali sebagai Pertubuhan Kastam Sedunia (WCO) kerana Malaysia secara efektifnya telah menjadi ahli kepada WCO pada tahun tersebut. Keahlian JKDM telah memaksa JKDMS untuk menerima pakai sebarang persefahaman yang telah digariskan oleh WCO khususnya dalam menangani operasi melibatkan perdagangan antarabangsa. Secara automatik juga, sistem perakaunan JKDMS khususnya yang melibatkan percukaian barangan perdagangan antarabangsa. Walau bagaimanapun, pada tahun-tahun awal kemerdekaan ini tidak banyak yang berubah dari segi sistem perakaunan JKDMS kerana aktiviti perdagangan melibatkan perdagangan antarabangsa adalah kecil secara perbandingannya.

\section{Era Tahun 1970an}

Era tahun 1970an merupakan satu tempoh dalam sejarah Malaysia yang melakar sejarah sebagai titik tolak kepada pembangunan negara khususnya yang berkaitan dengan pembangunan fizikal infrastruktur negara. Hal ini adalah berkait rapat dengan dasar pembangunan dan pentadbiran Malaysia pada ketika itu.

Sejak awal kemerdekaan sehingga akhir 1969 menampakkan bahawa agak sukar bagi pembangunan fizikal negara untuk dilakukan pada ketika itu kerana pemimpin nombor satu negara pada ketika itu iaitu Tunku Abdul Rahman perlu menumpukan usaha dan tenaga untuk menyatupadukan kaum dan juga untuk membendung kegiatan komunis Malaya. Walau bagaimanapun, kejayaan Tunku Abdul Rahman dalam menangani permasalahan negara khususnya yang berkaitan dengan kegiatan komunis telah membuka jalan yang luas kepada perdana menteri seterusnya iaitu Tun Haji Abdul Razak bin Dato' Haji Hussein yang juga dikenali sebagai Bapa Pembangunan negara untuk memacu pembangunan negara khususnya dari segi infrastruktur dan juga ekonomi.

Dari sudut pembangunan ekonomi, negara telah membuat perancangan jangka panjang yang menampakkan hasil yang memberangsangkan menerusi Rancangan Malaysia (RMK) yang melibatkan tempoh setiap 5 tahun bermula dengan RMK 1 pada tahun 1965. Ini ditambah lagi dengan perlaksanaan Dasar Ekonomi Baru yang diperkenalkan bermula pada tahun 1971 sebagai inisiatif untuk menghapuskan kemiskinan khususnya di kalangan kaum bumiputera, di samping inisiatif untuk mengurangkan jurang pegangan ekuiti ekonomi antara kaum yang disifatkan sebagai punca rusuhan kaum pada 13 Mei 1969.

Implikasi ke atas JKDM secara keseluruhan hasil daripada inisiatif pihak kerajaan di peringkat pusat adalah untuk menangani kesan ledakan pembangunan aktiviti ekonomi dalam dan luar negara yang memberi kesan kepada aktiviti perkastaman di Malaysia khususnya dari sudut pungutan cukai perdagangan. Untuk menangani kesan ke atas perdagangan negara hasil ledakan pembangunan ekonomi ini, pihak JKDM akhirnya menggubal dan mengaplikasi dua akta utama iaitu Akta Jualan 1972 dan juga Akta Perkhidmatan 1975. Kedua-dua akta ini dan juga akta-akta lain yang berkaitan telah banyak mengubah sistem dan amalan perkastaman dalam menangani aktiviti perdagangan dan ekonomi dalam negara.

\section{Era Tahun 1970an: Implikasi}

Dari segi implikasinya kepada sistem dan amalan perakaunan pengurusan di JKDMS, secara automatik ianya harus atau 'terpaksa' menerima pakai sebarang peraturan atau kaedah perakaunan 
pengurusan yang telah digariskan oleh pihak Kementerian Kewangan Malaysia dan juga JKDM pusat berdasarkan Akta Jualan 1972 dan juga Akta Perkhidmatan 1975. Dalam erti kata lain, kedua-dua akta ini telah mewujudkan satu sistem dan amalan perakaunan pengurusan yang baharu berkaitan dengan kutipan cukai dan juga perbelanjaan JKDMS dalam menangani aktiviti jualan dan perkhidmatan yang dilakukan oleh para peniaga dalam negeri Sabah.

\section{Era tahun 1980an}

Secara umumnya, seperti yang telah dinyatakan dalam subtopik yang sebelumnya, tidak banyak perubahan yang berlaku dalam sistem perakaunan pengurusan JKDMS sejak era kemerdekaan pada tahun 1963. Hal ini juga berterusan sehingga akhir tahun 1970an. Walau bagaimanapun, era 1980an khusunya menghampiri 1990an terdapat beberapa perubahan di peringkat global dan nasional yang telah memaksa JKDMS untuk turut berubah termasuklah perubahan dalam sistem dan amalan perakaunannya. Pada dasarnya perubahan ini adalah adalah selaras dengan dasar di peringkat negara yang berusaha ke arah pemodenan dan pembaharuan sistem pentadbiran kerajaan agar menjadi lebih efektif dan efisien melalui Dasar Pandang Ke Timur seperti yang diilhamkan oleh YAB Perdana Menteri pada ketika itu, Tun Mahathir Mohamad.

\section{Era tahun 1980an: Implikasi}

Menurut seorang pegawai kanan JKDMS yang telah ditemubual, pada tahun-tahun 1980 beliau pernah di hantar berkursus beberapa kali ke luar negara khususnya di negara Jepun dan Korea. Beliau menjelaskan bahawa mereka dihantar ke sana untuk mempelajari mengenai sistem dan budaya pentadbiran agensi perkastaman di negara-negara tersebut. Ini termasuklah budaya kerja harian mereka, sistem pengurusan pejabat dan pekerja, kualiti kerja dan sebagainya. Apabila diajukan soalan lanjut mengenai tujuan utama di sebalik kursus tersebut, beliau menyatakan:

\footnotetext{
“ Kami terdiri dari beberapa orang pegawai muda yang dihantar berkursus. Kalau saya melihat kami dihantar untuk mempelajari sistem dan budaya mereka untuk dibawa ke sini. Saya dapat rasakan yang JKDM mahukan kami meniru cara mereka. Jepun memang terkenal sebagai negara yang mempunyai sistem perkastaman terbaik di dunia"
}

Walau bagaimanapun, tidak banyak yang boleh dikaitkan dengan kesan kepada JKDMS dari segi perubahan kepada sistem dan amalan perakaunan pengurusan secara spesifik. Apa yang dapat disimpulkan melalui temubual tersebut bahawa sememangnya terdapat usaha yang serius di peringkat JKDMS untuk menerapkan nilai-nilai positif yang mereka pelajari dari negara tersebut. Ini bermakna, secara tidak langsung sistem perkastaman JKDMS termasuklah melibatkan aktiviti kutipan hasil cukai dan sistem perakaunan juga telah mengambil kira sistem dan budaya yang mereka pelajari dari negaranegara tersebut.

\section{Era Tahun 1990an}

Tahun 1990an merupakan satu tempoh yang agak mencabar bukan hanya di JKDM peringkat nasional tetapi juga di JKDMS. Terdapat beberapa peristiwa peringkat global dan nasional yang telah memberi impak samada secara langsung mahupun tidak langsung kepada JKDMS.

Pada ketika ini antara fenomena global yang melanda negara adalah letusan penggunaan teknologi dalam pentadbiran kerajaan termasuklah juga di JKDMS. Sistem dan amalan kerja di semua peringkat JKDMS telah banyak berubah dari sistem manual kepada sistem berasaskan komputer atau teknologi. Sebagai contoh, kebanyakan sistem perekodan aktiviti kastam JKDMS telah menggunakan komputer dan pada masa yang sama mengurangkan kaedah perekodan menggunakan sistem manual.

Selain dari kesan pembangunan dan gelombang teknologi di peringkat global, JKDMS juga tidak terkecuali dari menerima tempias globalisasi khususnya yang dikaitkan dengan sistem pentadbiran awam baharu atau NPM. Sebagai sebuah badan kerajaan, JKDMS tidak mempunyai pilihan melainkan 
untuk melakukan inisiatif pembaharuan pentabiran berasaskan NPM. Antara penerapan budaya yang dilakukan di peringkat JKDMS adalah peningkatan produktiviti, kualiti kerja dan amalan mengutamakan pelanggan di samping mewujudkan budaya kerja yang berketrampilan berlandaskan prinsip imej positif di kalangan pegawai-pegawai kastam khususnya mereka yang berurusan secara langsung dengan masyarakat luar.

Tekanan paling besar yang dialami bukan sahaja di JKDMS tetapi di peringkat nasional adalah kegawatan ekonomi serantau yang melanda negara-negara asia pada lewat 1990an dan juga laporanlaporan ketirisan hasil yang dialami oleh JKDM secara kesuluruhan. Laporan-laporan akhbar khususnya yang bersifat negatif terhadap kredibiliti JKDM sebagai pemungut hasil bagi pihak kerajaan telah memaksa JKDM termasuk JKDMS untuk melihat semula sistem operasi perkastaman mereka. Pada masa yang sama, terdapat desas desus yang mengatakan bahawa terdapat sebilangan pegawai-pegawai atasan di JKDM termasuk di Sabah yang bertindak menentang kerajaan memerintah (Tajuddin, 2005) yang mengakibatkan wujudnya cadangan untuk merombak sistem dan struktur organisasi JKDM secara keseluruhan.

\section{Implikasi ke Atas Sistem dan Amalan Perakaunan Pengurusan}

Antara implikasi ke atas sistem dan amalan perakaunan pengurusan hasil daripada beberapa fenomena atau insiden yang berlaku pada era tahun 1990an dan sebelumnya ialah penggunaan teknologi dalam perlaksanaan atau proses perakaunan pengurusan di JKDMS, sekurang-kurangnya di peringkat perekodan. Seorang ketua Stesen yang ditemubual menyatakan:

"Saya mula masuk bertugas di sini pertengahan 1990, sekitar 1995-1996. Apa yang saya boleh katakan mengenai perubahan pada waktu itu ialah kita sibuk memindahkan rekod-rekod menggunakan komputer dari rekod manual. Ini hampir semua aspek termasuk rekod aset, kewangan dan sebagainya"

Berkenaan dengan isu globalisasi, ketirisan, kegawatan ekonomi dan juga ketidakpuasan hati dari masyarakat umum ke atas JKDM, pihak JKDMS juga terpaksa membuat beberapa pendekatan. Temubual dengan salah seorang ketua Stesen di JKDMS menyatakan antara pendekatan yang mereka buat ialah melakukan operasi atau tindakan berkualiti. Beliau merujuk kepada konsep mengurangkan aktiviti kurang mendatangkan nilai tambah, dan pada masa yang sama meningkatkan hasil. Temubual seterusnya dengan pegawai bawahan beliau juga menunjukkan dapatan yang sama. Pegawai bawahan tersebut mengatakan:

\section{"Ketua saya sering menekankan kerja berkualiti. Tujuannya untuk meningkatkan hasil kutipan cukai"}

Berkenaan dengan implikasi kegawatan ekonomi kepada JKDMS, salah seorang pegawai kanan yang telah ditemubual menyatakan bahawa antara tindakbalas mereka ke atas kegawatan ekonomi yang dihadapi adalah mengurangkan perbelanjaan dalam aktiviti mereka. Beliau mengakui sebelum kegawatan ekonomi, tidak timbul soal kawalan keterlaluan ke atas operasi-operasi perkastaman seperti belanja bahan bakar bot dan sebagainya. Walau bagaimanapun, kegawatan ekonomi memaksa mereka menggunakan belanjawan yang telah diluluskan untuk mengawal dengan lebih ketat lagi setiap aktiviti yang melibatkan kewangan atau sumber-sumber JKDMS. Dari segi rekod, setiap perbelanjaan yang berlaku akan direkodkan dengan teliti, dan pegawai atasan yang terlibat diminta untuk memantau proses perekodan perbelanjaan tersebut setiap masa.

\section{Perbincangan Kajian}

\section{Perubahan Organisasi JKDMS}

Dapatan kajian menunjukkan bahawa ianya adalah selari dengan pandangan daripada para penyelidik terdahulu atau sarjana-sarjana dalam bidang ini yang menunjukkan bahawa JKDMS telah dan sedang 
mengalami perubahan organisasi yang disebabkan oleh faktor yang wujud di luar dan di dalam organisasi itu sendiri (Contoh: Khan dan Hashim, 2014; Lunernberg, 2010; Tahajuddin, 2013; Tahajuddin, 2020; Tahajuddin dan Sulaiman, 2021). Kajian-kajian terdahulu menunjukkan antara faktor atau daya luaran organisasi yang bertindak secara signifikan dalam proses perubahan ini adalah terdiri daripada globalisasi (Andreeva, 2008; Budai, 2011; Karoda dll., 2014; Rababa'h, 2014), perubahan teknologi (Contoh: Lim dan Yazdanifard 2014; Rababa'h, 2014; Lunenberg, 2010), dasar kerajaan (Contoh: Budai 2011; Costa dan Jaime, 2011), tekanan pihak atasan ( Contoh: Gilbert dll., 2012; Lunenberg, 2010; Tahajuddin, 2020) dan juga kegawatan ekonomi global (Khan dan Hashim, 2014; Sternad, 2010; Lowth dll., 2010, Skipper, 2009).

Secara teorinya, seperti yang dijelaskan dalam konsep Isomorfisme oleh DiMaggio dan Powell (1983), faktor-faktor perubahan ini merupakan sebahagian daripada elemen medan organisasi yang semestinya akan memberi impak dan tekanan sama ada dalam bentuk paksaan, normatif mahupun dalam bentuk mimetik.

Dalam kajian ini mendapati bahawa JKDMS telah terdedah kepada faktor luaran selari dengan apa yang telah diperkatakan oleh para sarjana di atas. Pada masa yang sama, terdapat juga faktor dalaman yang telah membawa perubahan kepada JKDMS sama ada di peringkat organisasi mahupun di peringkat sistem dan amalan perakaunan pengurusan.Sebelum kemerdekaan negeri Sabah bersama Persekutuan Malaysia pada 16 September 1963, sistem dan amalan perakaunan pengurusan yang terdapat di JKDMS khususnya yang melibatkan percukaian barangan dagangan adalah berdasarkan Ordinan-ordinan berkaitan yang diperturunkan dari era kolonial British. Walau bagaimanapun, keadaan tersebut mula beransur-ansur mengalami perubahan apabila negeri Sabah menjadi anggota dalam Persekutuan Malaysia tahun 1963. Walaupun JKDMS mendapat keistimewaan untuk bersifat autonomi dalam urusan perkastaman khususnya yang melibatkan percukaian tetapi pada hakikatnya keadaan ini mula berubah apabila secara perlahan-lahan JKDMS mula mengadaptasi sistem percukaian yang digunapakai di Semenanjung Tanah Melayu.

Seterusnya apabila kedatangan teknologi maklumat dan komunikasi, globalisasi dan NPM pada tahun 1990an telah mendorong JKDMS untuk turut serta membuat pembaharuan dalam sistem pengurusan mereka, ini termasuklah juga dalam sistem perakaunan pengurusan mereka apabila sistem perakaunan manual telah secara beransur-ansur ditukarkan kepada sistem berkomputer, dan pada masa yang sama mentaliti pengurusan JKDMS berasaskan NPM mula terserlah. Di peringkat global, penggunaan dan aplikasi teknologi, globalisasi dan NPM di negara maju dan membangun mendorong institusi pentadbiran kerajaan Malaysia untuk mengadaptasi perkembangan tersebut seterusnya menjadikannya satu amalan di semua peringkat kerajaan, agensi dan jabatan termasuk JKDMS. Perubahan ini adalah selari dengan teori Isomorfisme Normatif yang diterangkan oleh DiMaggio dan Powell (1983). Dapatan kajian ini juga adalah selari dengan dapatan-dapatan kajian terdahulu seperti Andreeva, 2008; Budai, 2011; Karoda d1l., 2014; Rababa'h, 2014 mengenai globalisasi dan perubahan; Rababa'h, 2014; Lim dan Yazdanifard, 2014; Cha dan Cha, 2014; dan Budai, 2011 mengenai kesan perkembangan teknologi ke atas perubahan organisasi dan juga Hassan, 2015; Lim dan Yazdanifard, 2014; Rababa'h, 2014 dan Siddique, 2006 mengenai kesan NPM ke atas perubahan organisasi.

\section{Perubahan Organisasi dan Perubahan Sistem dan Amalan Perakaunan Pengurusan JKDMS.}

Secara konsep atau teorinya, seperti yang dijelaskan oleh Laughlin (1991) dan juga Nadler dan Tushman (1980) menyatakan bahawa sebuah organisasi itu haruslah dilihat sebagai satu entiti sosial yang terdiri dari beberapa sistem kompleks yang saling bergantungan satu sama lain. Setiap perubahan dalam sistem ini akan menyebabkan keseluruhan sistem akan turut berubah. Dalam konteks ini, perakaunan pengurusan haruslah dilihat sebagai salah satu sistem yang terdapat dalam sesebuah organisasi. Ini bermakna secara teorinya, perubahan organisasi dan perubahan sistem dan amalan perakaunan dalam organisasi tersebut mempunyai perhubungan simbiosis, atau saling berkait.

Dapatan kajian ini menunjukkan bahawa, apabila JKDMS terdedah kepada tekanan luar khususnya dalam bentuk Isomorfisme Paksaan, maka organisasi JKDMS terpaksa mengubah elemen-elemen 
dalam organisasi sama ada di peringkat Skima Interpretif, Rekabentuk Archetype dan juga sub-sistem. Sebagai contoh, apabila Akta Kastam Malaysia 1967 digunapakai maka struktur dan sistem pentadbiran JKDMS turut berubah. Perubahan organisasi ini pula pada akhirnya memberikan implikasi yang menyebabkan sistem percukaian iaitu salah satu cabang dalam sistem dan amalan perakaunan pengurusan turut sama berubah sama ada secara langsung atau sebaliknya. Contoh ini menunjukkan bahawa perubahan organisasi (elemen lebih besar) akan mengubah sistem dan amalan perakaunan pengurusan. Pada masa yang sama, dapatan kajian ini juga menunjukkan bahawa perubahan pada sistem dan amalan perakaunan pengurusan akan turut sama mengubah organisasi tersebut dalam mana-mana elemen organisasi. Contohnya, apabila bilangan pegawai kastam yang berlatarbelakangkan akademik dan pengalaman perakaunan semakin bertambah di JKDMS, budaya kerja dan bahasa rutin di JKDMS turut berubah. Sebagai contoh, kewujudan pegawai tersebut sebagai satu institusi akhirnya menjadikan pemikiran dan amalan berdasarkan perakaunan pengurusan menjadi satu budaya dan bahasa kepada seluruh JKDMS. Dalam erti kata lain, perubahan dalam sistem dan amalan perakaunan akan menyebabkan organisasi berubah. Secara kesimpulannya, kedua-dua perubahan dalam organisasi dan sistem dan amalan perakaunan itu adalah saling berkait secara dua hala.

Dapat dirumuskan bahawa dapatan kajian dalam konteks perhubungan organisasi dan sistem dan amalan perakaunan ini adalah selari dengan dapatan atau pandangan daripada kajian dan para sarjana sebelum ini termasuklah Khan dan Hashim (2014); Sunarni (2013); Strumickas dan Valanciene (2009); Yadzifar dan Tsamenyi (2005); Laughlin (1991) dan juga Nadler dan Tushman (1980).

\section{Kesimpulan}

Objektif utama kajian ini dilakukan adalah untuk memahami bagaimana sistem dan amalan perakaunan pengurusan dalam konteks perubahan organisasi berlaku dalam era selepas kemerdekaan sehingga sebelum era Milenium bermula pada tahun 2000. Seperti yang telah dikatakan oleh majoriti sarjana dalam bidang ini termasuklah Arroyo (2012) dan Yadzifar dan Tsamenyi (2005), masih banyak lagi yang perlu diketahui mengenai perubahan perakaunan kewangan. Oleh itu, adalah dijangkakan bahawa kajian ini adalah bertepatan pada waktunya, dan dapatan kajian ini diharapkan akan menyumbang dari segi teori dan emprikal ke atas bidang ini.

Dapatan kajian ini adalah selaras dengan kajian-kajian terdahulu khususnya mengenai perananperanan institusi dalam mendorong perubahan ke atas organisasi dan juga sistem dan amalan perakaunan pengurusannya. Dapatan kajian menunjukkan bahawa faktor luaran organisasi antara lainnya seperti kegawatan ekonomi, krisis kewangan, politik, NPM, globalisasi, perkembangan teknologi, undang-undang dan peraturan mempunyai kesan yang signifikan ke atas organisasi yang akhirnya mendorong kepada perubahan dalamannya termasuklah perakaunan pengurusan.

\section{Rujukan}

Adler, J. J. \& Jelinek, M. (1986). Is "'Organization Culture" Culture 1 Bound?. Human Resource Management, 25(1), 73-90.

Andreeva, T. E. (2008). Can Organizational Change be Planned and Controlled? Evidence from Russian Companies. Human Resource Development International, 11(2), 119-134.

Anggestam, L. (2006). Learning Organization or Knowledge Management - Which Came First, the Chicken Or The Egg?. Information Technology and Control, 35(3), 295-302.

Arroyo, P. (2012). Management Accounting Change and Sustainability: An Institutional Approach. Journal of Accounting \& Organizational Change, 8(3), 286-309.

Aziz, S. A. (2017). Memahami Falsafah Raja Berpelembagaan. Berita Harian Online. http://www.bharian.com.my/node/270306\#cxrecs_s. dimuat turun pada 10 Aprl 2017.

Bailey, K. D. (1994). Methods of Social Research. 4th Edition. The Free Press.

Bouma, G. D. \& Atkinson, G. B. J. (1995). A Handbook of Social Science Research: A Comprehensive and Practical Guide For Students. Second Edition. Oxford University Press. 
Broadbent, J. \& Laughlin, R. (2005). Organisational and Accounting Change: Theoretical and Empirical Reflections and Thoughts on a Future Research Agenda. The Journal of Contemporary Accounting and Organizational Change, 1(1), 7-26.

Bruce, C. D. (2007). Question Arising about Emergence, Data Collection, and Its Interaction with Analysis in a Grounded Theory Study. International Journal of Qualitative Methods, 6(1), 1-12.

Bryant, M. (2006). Talking About Change: Understanding Employee Responses through Qualitative Research. Management Decision, 44(2), 246-258.

Budai, T. (2011). The Significance and History of Organization Development - in Hungary and International Relations. Eurasian Journal of Business and Economics, 4(8), 87-99.

Caccia, L. \& Steccoloni, I. (2006). Accounting Change in Italian Local Governments: What's Beyond Managerial Fashion?. Critical Perspectives on Accounting, 17, 154-174.

Cha, K. J. \& Cha, J. S. (2014). Information Technology Enabled Organizational Transformation: Toward an Integrative Theoretical Framework. International Journal of Multimedia and Ubiquitous Engineering, 9(2), 115-126

Cosimato, S. Torre, C. \& Troisi, O. (2015). How to Innovate Management Accounting For Public Sector: An Italian Case Study. Journal of US-China Public Administration, 12(9), 695-705.

Costa, K. J. \& Jaime, J. V. (2011). The Impact of Organisational Privatization on the Performance of Publicly Owned Enterprises. Advances in Management \& Applied Economics, 1(3), 1-29.

Christiaens, J. \& Rommel, J. (2008). Accrual Accounting Reforms: Only For Business-like (Parts of) Governments'. Financial Accountability and Management, 24(1), 59-75.

Dillard, J., Rogers, R. \& Yuthas, K. (2011). Organizational Change: in Search of the Golden Goal'. Journal of Accounting and Organizational Change, 7(1), 5-32.

DiMaggio, P. J. \& Powell, W. W (1983). The Iron Cage Revisited: Institutional Isomorphism and Collective Rationality in Organizational Fields. American Sociological Review, 48, 147-160.

Eriksson, A., Holden, R. J., Williams, A. \& Delive, L. (2016). A Case Study of Three Swedish Hospitals' Strategies for Implementing Lean Production'. Nordic journal of working life studies, 6(1)105-131.

Gilbert, F, Denis, J. L., Lamothe, L., Beaulieu, M. D., D’Amour, D. \& Goudreau, J. (2012). 'Reforming Primary Healthcare: From Public Policy To Organizational Change'. Journal of Health Organization and Management, 29(1), 92-110

Gurd, B. (2008). Structuration and middle-range theory - A case study of accounting during organizational change from different theoretical perspectives. Critical Perspectives on Accounting, 19, 523-543.

Hassan, M. M. (2015). Transformation to More-Accrual-Based Accounting Practices in Indonesian Government. Journal of International Business Research, 14(1), 147-173.

Horngren, C. T., Sundem, G. L., Burgstahler, D. \& Scharzberg, J. (2011). Introduction To Management Accounting - Global Edition'. Pearson Education Limited, Essex, England.

Innes, J., \& Mitchell, F. (1990). The Process of Change in Management Accounting: some field study evidence. Management Accounting Research, 1(1), 3-19.

Iqbal, U., Hussin, N. \& Seman, A. A. (2014). Landskap ekonomi Malaysia sebelum Dasar Ekonomi Baru: Peranan pelaburan Jepun. Malaysian Journal of Society and Space, 10(2), 168 - 177.

Kasurinen, T. (2002). Exploring Management Accounting Change: The Case of Balanced Scorecard Implementation. Management Accounting Research, 13(3), 323-343.

Khan, M. A. \& Hashim, M. (2014). Organizational Change: Case Study of General Motors. ASEE 2014 Zone I Conference, April 3-5, 2014, University of Bridgeport, Bridgeport, CT, USA, m.s. 15.

Laughlin, R. (1995). Empirical Research in Accounting: Alternative Approaches and a Case for "middle-range" thinking. Accounting, Auditing and Accountability Journal, 8(1), 63-87.

Laughlin, R. C. (1991). Environmental Disturbances and Organizational Transitions and Transformations: Some Alternative Models. Organization Studies, 12(2), 209-232.

Lim, W. S. \& Yazdanifard, R. (2014). A Multidimensional Review on Organizational Change's Perspectives, Theories, Models, and Types of Change: Factors Leading to Success or Failure Organizational Change'. Global Perspective on Engineering Management, 3(2), 27-33.

Lind, J. (2001). Control in World Class Manufacturing - A Longitudinal Case Study. Management Accounting Research, 12, 41-74. 
Lowth, G., Prowle, M. \& Zhang, M. (2010). The impact of economic recession on business strategy planning in UK companies. CIMA Research executive summary series, 6(9), 1-10.

Lunenberg, F. C. (2010). Forces for and Resistance to Organizational Change. National Forum of Educational Administration and Supervision Journal, 27(4), 1-10.

Malhotra, N. \& Hinnings, C. R. (2015). Unpacking Continuity and Change as a Process of Organizational Transformation. Long Range Planning, 48, 1-22.

MAMPU, Pelbagai Rujukan. http://www.mampu.gov.my/ms/info-korporat/sejarah-mampu.

Mathison, S. (1988). Why Triangulate?. Educational Researcher, 13-17.

Molainen, S. (2008). The Role of Accounting and an Intermediate Subsidiary in the Management Control System. Management Accounting Research, 19, 252-269.

Nadler, D. A. \& Tushman, M. L. (1980). A Model for Diagnosing Organizational Behavior: Applying a Congruence Perspective. Organization Dynamics, 35-48.

Nieves, J. \& Siegarra-Ciprés, M. (2015). Management Innovation in the Hotel Industry. Tourism Management, 46, 51-58.

Otley, D. (1990). Issues in Accountability and Control: Some Observations from a Study of Colliery Accountability in the British Coal Corporation. Management Accounting Research, 1, 101-123.

Patton, M. Q. (1999). 'Enhancing the Quality and Credibility of Qualitative Analysis'. Health Services Research, 34(5), 1189-1208.

Pelan Transformasi Kerajaan - Pelan Hala Tuju: Ringkasa Exekutif, PEMANDU. http://www.pmo.gov.my/GTP/documents/Pelan\%20Hala\%20Tuju\%20GTP\%20-

\%20Ringkasan\%20Eksekutif/Pelan\%20Hala\%20Tuju\%20GTP\%20\%20Ringkasan\%20Eksekutif.pdf

Pertubuhan Bangsa-Bangsa Bersatu (2011). Measuring the Impacts of Information and Communication Technology for Development. United Nations Conference on Trade and Development, 1-31.

Pertubuhan Bangsa-Bangsa Bersatu. (1995). Improving the Efficiency of the Public Sector: A CaseStudy of Malaysia. Twelfth Meeting of Experts on the United Nations Programme in Public Administration and Finance New York, 31 July-11 August 1995. Dimuat turun dari: http://unpan1.un.org/intradoc/groups/public/documents/un/unpan000762.pdf

Pundziene, A. \& Duobiene, J. (2006) 'CEOs' Entrepreneurship in Relation to Reaction to Organizational Change'. Engineering Economics, 2(47), 91-98.

Rababa'h, A. Q. (2014). The Implementation of Management Accounting Innovations: The Case of Balanced Scorecard Implementation within Jordanian Manufacturing Companies. International Review of Management and Business Research, 3(1), 174-181.

Rabionet, S. E. (2011). How I learned to Design and Conduct Semi-Structured Interviews: An Ongoing and Continuous Journey. The Qualitative Report, 16(2), 563-566.

SBU. (2014). Evaluation and synthesis of studies using qualitative methods of analysis. Stockholm: Swedish Agency for Health Technology Assessment and Assessment of Social Services (SBU).

Scapens, R. W. (2006). Understanding management accounting practices: A personal journey. The British Accounting Review, 38(1), 1-30.

Seawright, J. \& Gerring, J. (2008). Case Selection Techniques in Case Study Research: A Menu of Qualitative and Quantitative Options. Political Research Quarterly, 61, 294.

Siddiquee, N. A. (2006). Public Management Reform in Malaysia Recent Initiatives and Experiences. International Journal of Public Sector Management, 19(4), 339-358.

Skipper, D. A. (2009). Organizational Design during the Financial Crisis. Journal of Strategic Leadership, 2(1), 57-69.

Stefura, G. (2014). Using Methodological Triangulation to Study the Individual Compliance Behaviour towards Income Reporting. SEA - Practical Application of Science, 11(3), 582-587.

Sternad, D. (2012). Adaptive Strategies in Response to the Economic Crisis: A Cross-Cultural Study in Austria and Slovenia. Managing Global Transitions, 10(3)257-282.

Strumickas, M., \& Valanciene, L. (2009). Research of management accounting changes in Lithuanian business organizations'. Inzinerine Ekonomika-Engineering Economics, 3, 26-32.

Sunarni, C. W. (2013). Management Accounting Practices and the Role of Management Accountant: Evidence from Manufacturing Companies throughout Yogyakarta, Indonesia. Review of Integrated Business and Economics Research, 2(2), 616-626. 
Tahajuddin, S. (2013). Management Accounting System and Practice Change in Malaysian Local Government: A Case Study of Kota Kinabalu City Hall. Unpublished Ph.D thesis, University of Essex, $U K$.

Tahajuddin, S. (2020). The Employees' Organizational Commitment Impact on Organizational Change - The Introduction of New Work Strategy. International Journal of Research in Engineering, Science and Management, 3(12), 71-74.

Tahajuddin, S., Singh, R. K. S. \& Buglayan, A. H. (2020). The Employees' Organizational Commitment towards Organizational Change: A Quantitative Study Approach on the Malaysian Goods and Services Tax (GST) Implementation. American Journal of Humanities and Social Sciences Research, 4(12), 280-287.

Tahajuddin, S. \& Sulaiman, N. N. (2021). Malaysian Government Choice of Fiscal and Monetary Policies during Covid-19 Pandemic: Preliminary Insigh'. International Journal of Advances in Engineering and Management, 3(1), 248-253

Tessier, S. \& Otley, D. (2012). From Management Controls to the Management of Controls. Accounting, Auditing and Accountability Journal, 25(5), 776-805.

Tsamenyi, M., Cullen, J., \& Gonzalez J. M. G. (2006). Changes in Accounting and Financial Information System in a Spanish Electricity Company: A New Institutional Theory Analysis. Management Accounting Research, 17, 409-432.

Turner, D. W. (2010). Qualitative Interview Design: A Practical Guide for Novice Investigators. The Qualitative Report, 15(3), 754-760.

Tyre, M. J., \& Hauptman, O. (1992). Effectiveness of Organizational Responses to Technological Change in the Production Process. Organization Science, 3(3), 301-320.

Van De Ven, A. H. \& Poole, M. S. (1995). Explaining Development and Change in Organization. Academy of Management Review, 20(3), 510-540.

Vasile, D. (2014). Copying with Organizational Change in the Tourism Industry. Cactus Tourism Journal, 10(2), 8-17.

Wezel, F. C. \& Saka-Helmhout, A. (2005). Antecedents and Consequences of Organizational Change: 'Institutionalizing' the Behavioural Theory of the Firm. Organization Studies, 27(2), 265-286.

Williams, C. (2007). Research Methods. Journal of Business and Economic Research, 5(3), 65-73.

YAB Perdana Menteri Dato' Seri Najib Tun Razak, 'Ucapan Bajet Tahun 2015'. http://www.pmo.gov.my/bajet2015/Bajet2015.pdf. Dimuat turun 14 April 2017.

Yazdifar, H. \& Tsamenyi, M. (2005). Management Accounting Change and The Changing Roles of Management Accountants: A Comparative Analysis Between Dependent and Independent Organizations. Journal of Accounting and Organizational Change, 1(2), 180 - 198.

Yeasmin, S. \& Rahman, K. F. (2012). 'Triangulation' Research Method as the Tool of Social Science Research. BUP Journal, 1(1)154-163.

Zia ul Haq, M. \& Kamran, M. (2015). Culture and Complexity: Organizational Change Influenced By Cultural Effects. International Journal of Computer and Communication System Engineering (IJCCSE), 2(3), 544-546. 